DOI: https://doi.org/10.24127/ajpm.v10i2.3734

\title{
PENGEMBANGAN PEMBELAJARAN MODEL GRUP INVESTIGASI BERBASIS PENALARAN BERBANTUAN SOAL OPEN-ENDED PADA KURIKULUM MATEMATIKA SMP
}

\author{
Moh. Mahfud Effendi ${ }^{1 *}$, Silvia Irene ${ }^{2}$ \\ ${ }^{1 *, 2}$ Pendidikan Matematika, Universitas Muhammadiyah Malang, Malang, Indonesia \\ * Universitas Muhammadiyah Malang, Malang, Indonesia. \\ E-mail: $\quad$ mahfud@umm.ac.id $^{\left.1^{*}\right)}$
}

Received 20 May 2021; Received in revised form 30 June 2021; Accepted 02 July 2021

\begin{abstract}
Abstrak
Tujuan kurikulum dapat dicapai dengan cara mengimplementasikannya dalam bentuk pembelajaran di kelas melalui model pembelajaran tertentu. Rendahnya penalaran siswa SMP menunjukan proses pembelajaran tidak berjalan secara efektif dan efisien, untuk itu memerlukan pengembangan model pembelajarannya. Atas dasar itulah, maka tujuan penelitian ini adalah pengembangan pembelajaran model Grup Investigasi berbasis penalaran berbantuan soal open-ended pada Kurikulum Matematika SMP. Metode yang digunakan untuk menghasilkan produk berupa perangkat pembelajaran matematika yang dapat meningkatkan penalaran matematika siswa, adalah metode research and development $(R \& D)$. Sedangkan data diperoleh melalui teknik dokumen, observasi, angket, dan tes. Berdasarkan uji validitas, perangkat pembelajaran yang dihasilkan dinyatakan valid/layak dan bisa digunakan. Sedangkan hasil uji coba dalam praktik pembelajaran di SMPN 3 Batu, Malang, Jawa Timur, Indonesia didapat bahwa uji keterlaksanaan dalam kategori sangat sesuai, sikap siswa baik, dan dapat meningkatkan penalaran matematika siswa, tetapi penalarannya menjadi lebih heterogin. Untuk mengetahui peningkatan penalaran, maka menggunakan instrument tes berbasis penalaran yang sudah divalidasi pada pre-test dan post-test. Hasil posttest lebih tinggi dari pretest, dan ada perbedaan yang signifikan antara keduanya, dengan t-tes $=-10,54$, dan sig. $(2$-tailed $)=0,000$. Hal ini menunjukan bahwa pembelajaran model Grup Investigasi berbasis penalaran berbantuan soal-soal open-ended ini dapat dan layak digunakan dalam Kurikulum Matematika di SMP.
\end{abstract}

Kata kunci: kurikulum matematika SMP, model grup investigasi, open-ended, penalaran

\begin{abstract}
Curriculum objectives can be achieved by implementing them in the classroom through a learning model. The low of reasoning of Junior High School (JHS) students shows that the learning process is ineffective and inefficient, so that it requires the development of a learning model. On this basis, the purpose of this research is to develop a learning Group Investigation Model based on reasoning with open-ended questions in the JHS Mathematics Curriculum. the method used to produce mathematics learning tools that can improve students' mathematical reasoning is the research and development method. While the data were obtained through document, observation, questionnaires, and tests techniques. Based on the validity test, the learning tools developed are valid and can be used. Meanwhile, the results of the learning test at SMPN 3 Batu, Malang, East Java, Indonesia, is was found that the feasibility test was very suitable, the student's attitude was good, and it could improve students' mathematical reasoning, but their reasoning becomes more heterogeneous. To find out the increase in students' reasoning, then using reasoning tests that have been validated in the pre-test and post-test. The posttest result was higher than the pretest, and there was a significant difference between the two, with $t$-test $=-10.54$, and sig. (2-tailed) $=0.000$. This shows that the Group Investigation model learning based on reasoning with open-ended questions is suitable for use in the JHS Mathematics Curriculum.
\end{abstract}

Keywords: investigation group model, JHS mathematics curriculum, open-ended, reasoning

This is an open access article under the Creative Commons Attribution 4.0 International License 
DOI: https://doi.org/10.24127/ajpm.v10i2.3734

\section{PENDAHULUAN}

Tujuan kurikulum matematika masih sulit dicapai, karena sebagian besar siswa masih merasa kesulitan memahami pelajaran matematika (Gazali, 2016). Kesulitan ini nampak dari rendahnya pemahaman siswa SMP terhadap matematika, paling tidak dalam 3 tahun berturut-turut, yaitu tahun 2014, 2015, dan 2016 (Permendikbud, 2016). Banyak faktor yang mempengaruhi, antara lain rendahnya kepercayaan diri, lemahnya proses berpikir, strategi pemecahan masalah matematika (Ario, 2016; Hidayati \& Widodo, 2015; Fatah, Suryadi, Sabandar, \& Turmudi, 2016), dan bermuara pada kemampuan bernalar.

Pemahaman dapat terbentuk jika siswa mempunyai penalaran yang baik. Oleh karenanya, dalam kurikulum matematika SMP, penalaran merupakan unsur penting dan sangat diperlukan dalam berpikir matematika khususnya terkait dengan menganalisis dan membuat kesimpulan (Hidayati \& Widodo, 2015; Kurniati, Harimukti, \& Jamil, 2016). Dalam implementasi di kelas, siswa harus terlibat langsung sehingga terbentuk pola pikir dan penalaran yang baik (Fitri, Rahma;Helma;Syarifudin, 2014; Gazali, 2016). Penalaran yang baik ini dapat membantunya dalam menyelesaikan masalah matematika (Riyanto \& Siroj, 2014; Incikabi, Tuna, \& Biber, 2013). Selain itu, kemampuan bernalar juga dapat membantu siswa menemukan konsep baru atau menggabungkan beberapa konsep sehingga menjadi konsep baru.

Penggunaan model pembelajaran menjadi satu pilihan yang efektif untuk memfasilitasi dan menumbuhkembangkan penalaran (Fuadi, 2016). Keterlibatan siswa dalam investigasi, melakukan penyelidikan, dan berdiskusi dapat membantu siswa mengembangkan penalarannya (Riyanto \& Siroj, 2014; Nataliasari, 2014; Hidayati \& Widodo, 2015; Pelu, 2020). Untuk itu, guru harus memberikan kesempatan bagi siswa untuk melakukannya dalam pembelajaran (Fuadi, 2016). Pemberian kesempatan ini dapat dilakukan dengan pembelajaran kooperatif model Grup Investigasi (GI).

Pembelajaran Model GI merupakan pembelajaran yang kegiatan intinya adalah investigasi secara berkelompok (Seran, Sujadi, \& Taufiq, 2020; Wicaksono, Sagita, \& Nugroho, 2017). Kegiatan investigasi dalam model GI ini, memaksa siswa terlibat secara aktif dalam pemecahan masalah, dan ini dapat melatih dan meningkatkan kemampuan bernalarnya (Gurbuz, 2013; Iswardati, 2016; Pitoyo, Waluyo, \& Suwandi, 2014). Untuk lebih memaksimalkan penalaran siswa dalam pembelajaran model GI, maka perlu dilengkapi dengan soal-soal open-ended (Munroe, 2015; Hafidzah, Azis, \& Irvan, 2021; Keh \& Ismail, 2015)

Ada dua penelitian terkait model GI dan open-ended, pertama, penelitian Suprianto, Noer, \& Rosidin (2020), tentang pengembangan pembelajaran model group investigation berbantuan soal open-ended untuk meningkatkan kemampuan berpikir reflektif matematis. Sedangkan yang kedua, penelitian Sirad, La Ode, Gemi Susanti, dan Rasidahtul Adawiah (2020), tentang penerapan model pembelajaran kooperatif tipe investigation dengan pendekatan open ended problem untuk meningkatkan kemampuan representasi matematis. Kemampuan representasi dan refleksi memerlukan kemampuan bernalar (NCTM, 2000), atau kemampuan bernalar menjadi syarat untuk mampu merepresentasi dan merefleksi. 
Berdasarkan uraian diatas, maka masalah penelitian ini difokuskan pada pengembangan pembelajaran model GI berbasis penalaran berbantuan soal-soal open-ended pada kurikulum matematika SMP. Tentu saja tujuannya adalah menghasilkan desain program pembelajaran matematika yang dapat meningkatkan penalaran matematika siswa SMP. Dengan demikian, desain pembelajaran ini diharapkan dapat menjadi pedoman dan membantu guru dalam melaksanakan pembelajaran matematika khususnya dalam mengembangkan dan meningkatkan penalaran siswa SMP.

\section{METODE PENELITIAN}

Sesuai dengan judul maka metode penelitian yang digunakan adalah metode Research and Development (R\&D), dengan menggunakan model pengembangan Borg dan Gall. Sedangkan tahapan pengembangannya dapt dilihat pada Gambar 1.

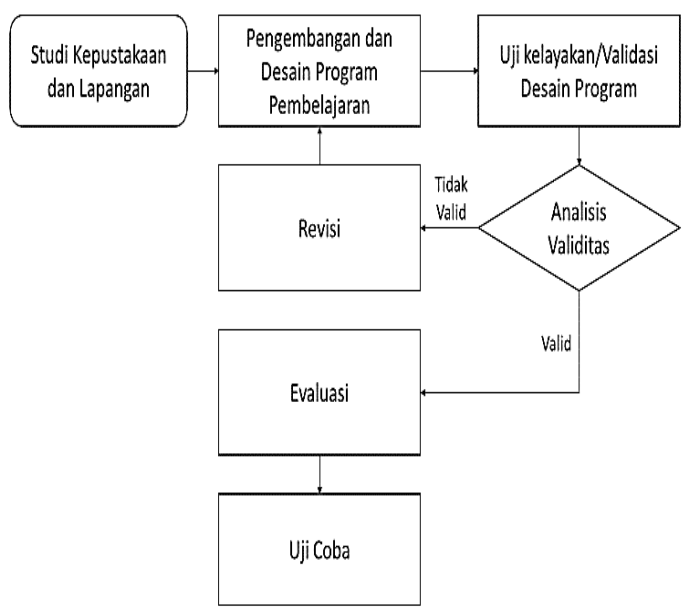

Gambar 1: Tahapan Pengembangan

Pada tahap awal dilakukan studi kepustakaan dan studi lapang. Studi kepustakaan mengkaji berbagai referensi baik literatur maupun jurnal terkait dengan masalah penelitian, sedangkan studi lapangan mengkaji

berbagai masalah khusunya terkait dengan rendahnya penalaran siswa di SMP. Dari tahap awal ini didapat beberapa konsep dan implementasi tentang model GI, penalaran, kurikulum dan pembelajaran matematika di SMP. Dari hasil konfirmasi dan cross check melalui dokumen dan wawancara ditemukan bahwa diperlukan pengembangan pembelajaran model GI berbasis penalaran berbantuan soal-soal open-ended

Pengembangan desain program pembelajaran mencakup rencana program, LKS, instrumen sikap, dan soal pretest dan posttest berbasis penalaran. Penelitian dan pengembangan ini difokuskan pada desain pembelajaran model GI berbasis penalaran berbantuan soal-soal openended pada Tabel 1.

Tabel 1. Pengembangan model GI

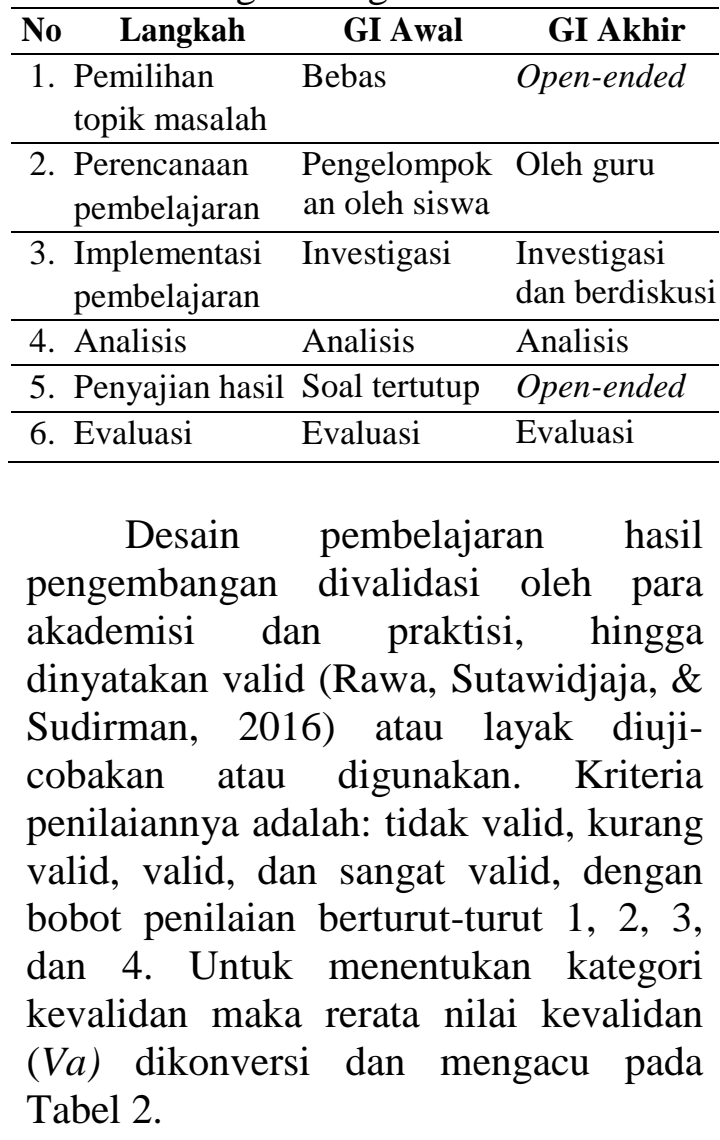


DOI: https://doi.org/10.24127/ajpm.v10i2.3734

Tabel 2. Interval dan kriteria kevalidan (Va)

\begin{tabular}{ccl}
\hline No & Interval & \multicolumn{1}{c}{ Kriteria } \\
\hline 1. & $1 \leq V a<2$ & Tidak valid (revisi total) \\
\hline 2. & $2 \leq V a<3$ & Kurang Valid (revisi sebagian \\
\hline 3. $3 \leq V a<4$ & Valid (tidak revisi) \\
\hline 4. & $V a=4$ & Sangat Valid (tidak revisi) \\
\hline
\end{tabular}

Pada tahap akhir dilakukan uji coba, yaitu menguji keterlaksanaan pembelajaran, uji sikap siswa, dan uji peningkatan penalaran. Uji coba dilakukan di klas VII-H dari seluruh kelas sebanyak 8 kelas, rata-rata perkelas 29 siswa, di SMP Negeri 3 Batu, Malang, Jawa Timur, Indonesia. Untuk menguji keterlaksanaan (K), maka dilakukan uji kesesuaian melalui observasi terhadap 3 pertemuan pembelajaran, dengan 23 item butir penilaian yang ada dalam desain program pembelaran, yaitu 6 item di pendahuluan, 12 item di kegiatan inti, dan 5 item di penutup, termasuk kegiatan saintifik siswa. Kategori penilaiannya adalah: tidak sesuai, kurang sesuai, sesuai, dan sangat sesuai, dengan bobot penilaian berturutturut 1, 2, 3, dan 4 (Gay, L., Mills, G., \& Airasian, 2006; McMillan, 2004). Untuk menentukan rating scale, menggunakan tabel 3 (Kemendikbud, 2019).

Tabel 3. Interval dan kategori keterlaksanaan (K) dan sikap (S)

\begin{tabular}{ccl}
\hline No & Interval $(\%)$ & \multicolumn{1}{c}{ Kategori } \\
\hline 1. & $0 \leq \mathrm{K} / \mathrm{S}<60$ & Tidak Sesuai/Baik \\
\hline 2. & $60 \leq \mathrm{K} / \mathrm{S}<74$ & Kurang Sesuai/Baik \\
\hline 3. & $74 \leq \mathrm{K} / \mathrm{S}<88$ & Sesuai/Baik \\
\hline 4. & $88 \leq \mathrm{K} / \mathrm{S} \leq 100$ & Sangat Sesuai/Baik \\
\hline
\end{tabular}

Uji sikap (S) siswa saat pelaksanaan pembelajaran, meliputi aspek tanggung jawab, jujur, peduli, kerja sama, santun, percaya diri, dan disiplin (Nilasari, Effendi, \& Putri, 2020). Kategori sikap meliputi tidak baik, kurang baik, baik, dan sangat baik, dengan rating scale menggunakan Tabel 3. Untuk kepentingan keabsahan data maka menggunakan triangulasi teknik.

Untuk mengetahui adanya peningkatan penalaran, maka sebelum uji keterlaksanaan diadakan pretest dan setelahnya diadakan posttest. Masingmasing tes terdiri dari 4 soal bentuk uraian, dengan penyekoran skala 100 . Sedangkan indikator penalaran yang menjadi perhatian adalah: mampu memodelkan $\left(\mathrm{C}_{1}\right)$, menduga $\left(\mathrm{C}_{2}\right)$, memanipulasi $\left(\mathrm{C}_{3}\right)$, membuktikan $\left(\mathrm{C}_{5}\right)$, menyimpulkan $\left(\mathrm{C}_{6}\right)$, memeriksa kebenaran $\left(\mathrm{C}_{4}\right)$, serta membuat pola $\left(\mathrm{C}_{2}\right)$ dan menggeneralisasi $\left(\mathrm{C}_{6}\right)$ (Ario, 2016; Hidayati \& Widodo, 2015; Riyanto \& Siroj, 2014).

Adanya peningkatan penalaran ditandai dengan adanya perbedaan dari dua hasil tes tersebut, tentu saja hasil rerata posttest $\left(\mu_{2}\right)$ lebih baik dibanding rerata pretest $\left(\mu_{1}\right)$, sehingga pasangan hipotesis kerjanya adalah (McMillan, 2004) sebagai berikut:

Ho : $\left(\mu_{2}\right)<\left(\mu_{1}\right)$, tidak ada perbedaan penalaran

Ha: $\left(\mu_{2}\right) \geq\left(\mu_{1}\right)$, ada perbedaan penalaran

Untuk membuktikannya, menggunakan uji statistik-t berbantuan SPSS. Kriteria pengambilan keputusannya, yaitu jika Sig.(2-tailed) $<0,05$ maka $H_{0}$ ditolak, dan sebaliknya.

\section{HASIL DAN PEMBAHASAN}

Seperti disebutkan di metode, bahwa uji keterlaksanaan dilakukan di kelas VII semester II SMP Negeri 3 Batu, Malang, Jawa Timur, Indonesia, dengan materi ajar Aritmatika Sosial, selama 3 pertemuan. Kompetensi inti menjadi dasar pengembangan dari indikator penalaran dan model GI di kegiatan inti (Kemendikbud, 2019). 
Desain pembelajaran model GI yang dikembangkan ada pada langkahlangkahnya, yaitu pada langkah: 1, 2, 3, dan 5 (Tabel 1), yang ada di kegiatan inti. Pada langkah 1: Pemilihan topik bahasan yang awalnya bersifat bebas dikembangkan menjadi open-ended. Langkah 2: Pembentukan kelompok yang awalnya ditentukan oleh siswa, pada pengembangan dilakukan oleh guru, agar rata-rata kemampuan kelompok yang satu dengan lainnya relatif sama. Langkah 3: Pada implementasi tidak hanya investigasi tetapi juga berdiskusi, yaitu membahas atau mengerjakan LKS (Lembar Kerja Siswa) dengan soal-soal open-ended. Sedangkan pada langkah 5: guru meminta semua kelompok untuk mempresentasikan hasil kerja kelompoknya secara bergiliran, dan ditanggapi oleh kelompok lainnya. Tentu saja proses pembelajaran ini bersifat bermakna (Gazali, 2016) dengan berfokus pada penalaran berbantuan soal-soal open-ended.

Selain materi ajar, LKS-pun juga dikembangkan berbasis penalaran openended. Pengembangan LKS sebagai perangkat pembelajaran tidaklah mudah, karena selain harus sesuai dengan kompetensi dasar dan indikator, LKS harus mampu dipelajari secara mandiri. (Kemendikbud, 2019).

Perangkat pembelajaran model GI berbasis penalaran ini, yang terdiri dari desain program pembelajaran, LKS, instrumen pretest dan posttest sudah divalidasi oleh 4 dosen Pendidikan Matematika UMM, yaitu: Prof. Akhsanul In'am, PhD., Dr. Dwi Priyo Utomo, MPd., Siti Khoirulli U., MPd., dan Octavina Rizky UP, MPd., dan 4 guru matematika SMPN 3 Batu Malang, yaitu: Rofa Tri Yulianti, SPd., Moh. Syamsul Hadi, SPd., Nur Widya Sulistyaningrum, SSi., dan Wulan
Handayani, SPd. Dari hasil validasi didapat skor dengan rata-rata sebesar 3,46 dan ini masuk kategori valid dan tidak ada revisi (Tabel 2).

Uji coba dilaksanakan dalam 5 pertemuan, pertemuan 1 adalah pretest dan pertemuan 5 adalah posttest, sehingga pertemuan efektifnya sebanyak 3 kali. Dalam 3 pertemuan ini dilakukan observasi untuk mengetahui keterlaksanaannya dengan melihat tingkat kesesuaian dengan desain program pembelajaran hasil pengembangan, dan bagaimana sikap siswa terhadap pembelajaran model GI ini. Berdasarkan observasi didapat bahwa tingkat keterlaksanaannya mencapai skor rata-rata sebesar 89,3 dengan kategori sangat sesuai, sedangkan sikap siswa mencapai skor rata-rata sebesar 75,7 dengan kategori baik.

Tabel 4. Skor keterlaksanaan dan sikap siswa

\begin{tabular}{llcccc}
\hline \multirow{2}{*}{ No } & \multirow{2}{*}{ Aspek } & \multicolumn{4}{c}{ Skor Pertemuan } \\
\cline { 3 - 6 } & & $\mathbf{1}$ & $\mathbf{2}$ & $\mathbf{3}$ & Rerata \\
\hline 1. Keterlaksanaan & 87 & 90 & 91 & 89,3 \\
2 & Sikap siswa & 73 & 78 & 76 & 75,7
\end{tabular}

Skor keterlaksanaan meningkat dari pertemuan 1, 2, dan 3, tetapi pertemuan 2 ke 3 kenaikannya tidak signifikan, hal ini dikarenakan sikap siswa yang kurang optimal dalam berdiskusi, cendrung pasif, takut salah dan kurang berani dalam berpendapat, sehingga beberapa indikator sikap kurang optimal terutama dalam hal tanggung jawab, peduli, dan kerja sama (Nilasari et al., 2020). Menurunnya skor sikap di pertemuan ke-3 ini, dipicu oleh $41,3 \%$ siswa yang skor sikapnya kurang optimal dalam pembelajaran model GI ini. Sikap siswa ini tentu berpengaruh terhadap pelaksanaan pembelajaran model GI di kelas.

Secara umum pembelajaran model GI ini dapat meningkatkan ratarata kemampuan penalaran siswa, hal 
ini bisa dilihat dari adanya perbedaan sebesar 17,45 dari hasil pretest sebesar 40,345 dan hasil posttest sebesar 57,793 (Tabel 6). Skor posttest lebih besar dari skor pretest mencerminkan adanya peningkatan kemampuan penalaran yang signifikan. Hal ini dapat dilihat pada Tabel 5, bahwa Sig.2-tailed (0.00) $<0,05$, maka $H_{0}$ ditolak atau $H_{a}$ diterima, artinya ada perbedaan penalaran yang signifikan.

Tabel 5: Deskrispi hasil uji statistik-t

\begin{tabular}{cccccc}
\hline \multicolumn{5}{c}{ Paired Differences Pretest-Posttest } \\
\hline Mean & SD & SE Mean & $\boldsymbol{t}$ & $\boldsymbol{d} f$ & Sig \\
\hline-17.45 & 8.91 & 1.66 & -10.54 & 28 & 0.00 \\
\hline
\end{tabular}

Hal yang sama juga disampaikan oleh Gurbuz (2013), Seran et al. (2020) dan Sobarningsih \& Rachmawati (2018) dalam penelitiannya bahwa pembelajaran model GI dapat mempengaruhi hasil belajar atau kemampuan penalaran matematika siswa. Apapun tipenya, ternyata pembelajaran kooperatif mampu meningkakan kemampuan penalaran (Nataliasari, 2014). Beberapa penelitian ini merupakan penelitian deskriptif kualitatif.

Walaupun pembelajaran model GI dapat meningkatkan kemampuan penalaran siswa, tetapi standar deviasinya menjadi lebih besar, dari 13,009 menjadi 16,304 (Tabel 6). Artinya, pembelajaran model GI ini juga berdampak pada kemampuan bernalar menjadi hiterogen, yaitu perbedaan penalaran antara yang rendah dan tinggi semakin lebar.

Tabel 6. Mean dan standar deviasi pretest dan posttest

\begin{tabular}{lcccc}
\hline & Mean & $\boldsymbol{N}$ & $\boldsymbol{S D}$ & $\boldsymbol{S E}$ Mean \\
\hline Pretest & 40.345 & 29 & 13.009 & 2.42 \\
Posttest & 57.793 & 29 & 16.304 & 3.03 \\
\hline
\end{tabular}

Pembelajaran model GI berbantuan soal open-ended ini mampu meningkatkan penalaran siswa, tetapi kemampuan penalaranya menjadi lebih heterogen. Penelitian ini melengkapi dan sejalan dengan hasil penelitian Suprianto, Noer, \& Rosidin (2020) yang berfokus pada kemampuan berpikir reflektif, dan hasil penelitian Sirad, La Ode, Gemi Susanti, dan Rasidahtul Adawiyah (2020) yang berfokus pada kemampuan representasi matematis. Kemampuan penalaran, refleksi, dan representasi merupakan standar proses, dimama kemampuan penalaran mendasari atau menjadi syarat seseorang mampu berpikir reflektif dan merepresentasi (NCTM, 2000).

Heterogennya kemampuan penalaran pada penelitian ini banyak dipengaruhi oleh faktor individual baik siswa maupun guru, antara lain sikap siswa, kreativitas guru dalam pembelajaran termasuk ketaatan terhadap prosedur model GI. Dua penelitian terdahulu belum mengungkap tentang homogen tidaknya kemampuan refleksi dan representasi. Hal ini penting untuk diketahui beserta faktor penyebabnya, karena menyangkut pada perbaikan program pembelajaran selanjutnya.

\section{KESIMPULAN DAN SARAN}

Berdasarkan hasil penelitian dan pembahasan dapat disimpulkan bahwa desain pembelaja-ran model GI berbasis penalaran berbantuan soal-soal openended dapat digunakan kurikulum dan pembelajaran matematika di SMP. Walaupun demikian, ada yang perlu ditindaklanjuti bahwa desain pembelajaran ini memang dapat meningkatkan kemampuan bernalar, tetapi kemampu-an bernalar siswa menjadi heterogen. Beberapa faktor yang menjadi penyebab dan bisa ditelusuri yaitu sikap siswa, penentuan kelompok diskusi, dan kreatifitas guru dalam implementasi. Jika faktor ini dapat ketahui maka akan menambah kesempurnaan penelitian ini. 


\section{DAFTAR PUSTAKA}

Ario, M. (2016). Analisis Kemampuan Penalaran Matematis Siswa SMK Setelah Mengikuti Pembelajaran Berbasis Masalah. Jurnal Ilmiah Edu Research, 5(2).

Fatah, A., Suryadi, D., Sabandar, J., \& Turmudi. (2016). Open-ended approach: An effort in cultivating students' mathematical creative thinking ability and self-esteem in mathematics. Journal on Mathematics Education, 7(1), 918. https://doi.org/10.22342/ jme.7.1.2813.9-18

Fitri, Rahma;Helma;Syarifudin, $\mathrm{H}$. (2014). Penerapan Strategi The Firing Line pada Pembelajaran Matematika Siswa Kelas XI IPS SMA Negeri 1 Batipuh. Jurnal Pendidikan Matematika, 3(1), 1822.

Fuadi, R. R. J. S. . (2016). Peningkatkan Kemampuan Pemahaman dan Penalaran Matematis melalui Pendekatan Kontekstual. Jurnal Didaktik Matematika, 3(1). https://doi.org/10.24815/jdm.v3i1. 4305

Gay, L., Mills, G., \& Airasian, P. (2006). Educational ResearchCompetencies for Analysis and Applications (8th Edition). Upper Saddler River, New Jersey: Pearson Education Inc.

Gazali, R. Y. (2016). Pembelajaran Matematika yang Bermakna. Math Didactic, 2(3). https://doi.org/ 10.33654/math.v2i3.47

Gurbuz, G. A. and F. (2013). Group Investigation Teaching Technique In Turkish Primary Science Courses. Balkan Physics Letters, 21(May).

Hafidzah, N. A., Azis, Z., \& Irvan, I. (2021). The Effect of Open Ended Approach on Problem Solving
Ability and Learning Independence in Students' Mathematics Lessons. IJEMS:Indonesian Journal of Education and Mathematical Science, 2(1). https://doi.org/10.30596/ijems.v2i1 .6176

Hidayati, A., \& Widodo, S. (2015). Proses Penalaran Matematis Siswa dalam Memecahkan Masalah Matematika pada Materi Pokok Dimensi Tiga Berdasarkan Kemampuan Siswa di SMA Negeri 5 Kediri. Jurnal Math Educator Nusantara, Vol 1(2).

Incikabi, L., Tuna, A., \& Biber, A. C. (2013). An Analysis Of Mathematics Teacher Candidates Critical Thinking Dispositions And Their Logical Thinking Skills. Journal of International Education Research (JIER), 9(3), 257-266. https://doi.org/10.19030/jier.v9i3.7 884

Iswardati, I. (2016). The Implementation of Group Investigation to Improve the Students' Speaking Skill. DINAMIKA ILMU, 16(2). https://doi.org/10.21093/di.v16i2.5 51

Keh, L. K., \& Ismail, Z. (2015). Preliminary study of creative problem solving on open-ended mathematical problems. International Journal of Innovation, Creativity and Change, 2(2).

Kemendikbud. (2019). Buku Penilaian Berorientasi Higher Order Thinking Skills. In Dirjen GTK. https://doi.org/10.37411/pedagogik a.v10i2.60

Kurniati, D., Harimukti, R., \& Jamil, N. A. (2016). Kemampuan berpikir tingkat tinggi siswa SMP di Kabupaten Jember dalam 
DOI: https://doi.org/10.24127/ajpm.v10i2.3734

menyelesaikan soal berstandar PISA. Jurnal Penelitian Dan Evaluasi Pendidikan, 20(2). https://doi.org/10.21831/pep.v20i2. 8058

McMillan, J. H. (2004). Educational Research: Fundamental for Consumer. HarperCollins CollegePublishers.

Munroe, L. (2015). The Open-Ended Approach Framework. European Journal of Educational Research, 4(3), 97-104. https://doi.org/10.12973/eu-jer.4.3.97

Nataliasari, I. (2014). Penggunaan Model Pembelajaran Kooperatif Tipe Think Pair Share (TPS) Untuk Meningkatkan Kemampuan Penalaran Dan Pemecahan Masalah Matematis Siswa MTS. Jurnal Pendidikan Dan Keguruan, 1(1).

NCTM. (2000). Principles and Standards for School Mathematics. In School Science and Mathematics.

Nilasari, A., Effendi, M. M., \& Putri, O. R. U. (2020). Analisis SelfConfidence dan Hasil Belajar Matematika SMA Dalam Kurikulum Berbasis Unit Kegiatan Belajar Mandiri. AKSIOMA: Jurnal Program Studi Pendidikan Matematika, 9(2). https://doi.org/10.24127/ajpm.v9i2. 2800

Pelu, M. (2020). Penerapan Model Pembelajaran Kooperatif Tipe Group Investigation (GI) Untuk Meningkatkan Keaktifan Bertanya dan Hasil Belajar Sejarah. Jurnal Candi, 20(1), 127-138.

Permendikbud. (2016). Peraturan Menteri Pendidikan dan Kebudayaan Republik Indonesia Nomor 22 Tahun 2016 tentang Standar Proses Pendidikan Dasar dan Menengah. Journal of Chemical Information and Modeling, 53(9).

Pitoyo, A., Waluyo, H. J., \& Suwandi, S. (2014). The Effect of Group Investigation Learning Model, Accelerated Learning Team and Role Playing on Elementary School Students, Writing Skills viewed from Cognitive Style. Journal of Education and Practice, 5(2), 95-104. Retrieved from www.iiste.org

Rawa, N., Sutawidjaja, A., \& Sudirman, S. (2016). Pengembangan Perangkat Pembelajaran Berbasis Model Learning Cycle 7E Pada Materi Trigonometri Untuk Meningkatkan Kemampuan Koneksi Matematis Siswa. Jurnal Pendidikan - Teori, Penelitian, Dan Pengembangan, 1(6).

Riyanto, B., \& Siroj, R. A. (2014). Meningkatkan Kemampuan Penalaran Dan Prestasi Matematika Dengan Pendekatan Konstruktivisme Pada Siswa Sekolah Menengah Atas. Jurnal Pendidikan Matematika, 5(2). https://doi.org/10.22342/jpm.5.2.581.

Seran, K. A., Sujadi, A. A., \& Taufiq, I. (2020). Pengaruh Model Pembelajaran Kooperatif Tipe Group Investigation (GI) Terhadap Hasil Belajar Matematika Siswa SMP. UNION: Jurnal Ilmiah Pendidikan Matematika, 8(1). https://doi.org/10.30738/union.v8i 1.5069

Sirad, L. O., Susanti, G., \& Adawiah, R. (2020). Penerapan Model Pembelajaran Kooperatif Tipe Investigation dengan Pendekatan Open-Ended Problem Untuk Meningkatkan Kemampuan Representasi Matematis. Jurnal Jupitek, 3(1) 23-32 DOI 
DOI: https://doi.org/10.24127/ajpm.v10i2.3734

https://doi.org/10.30598/jupitekvol 3iss1pp23-32

Sobarningsih, N., \& Rachmawati, T. K. (2018). Pengaruh Model Group Investigation dan Model Group Investigation dengan Afl Terhadap Hasil Belajar Matematika. Jurnal Penelitian dan Pembelajaran Matematika, 11(2). https://doi.org/10.30870/jppm.v11i 2.3761

Suprianto, T., Noer. S. H., Rosidin, U. (2020). Pengembangan Pembelajaran Model Group Investigation Berbantuan Soal Open-Ended untuk Meningkatkan kemampuan Berpikir Reflektif Matematis. AKSIOMA: Jurnal Program Studi Pendidikan Matematika, 9(1), 72-85. doi: https://doi.org/10.24127/ajpm.v9i1. 2583

Wicaksono, B., Sagita, L., \& Nugroho, W. (2017). Model Pembelajaran Group Investigation (GI) dan Think Pair Share (Tps) Terhadap Kemampuan Berpikir Kritis. AKSIOMA, 8(2). https://doi.org/10.26877/aks.v8i2.1 876 